\title{
Potensi Pengembangan Ayam Buras Di Nagari Silokek Kabupaten Sijunjung Sebagai Kawasan Geopark
}

\section{Potential Development of Free-range Chickens in Nagari Silokek Sijunjung Regency as a Geopark Area}

\author{
Hera Dwi Trianii ${ }^{1}$, Riza Andesca Putra ${ }^{2)}$ dan Rini Elisia ${ }^{1)}$ \\ ${ }^{1)}$ Sekolah Tinggi Ilmu Pertanian (STIPER) Sawahlunto Sijunjung \\ ${ }^{2)}$ Fakultas Peternakan Universitas Andalas, Padang \\ Email: heratriani@gmail.com
}

$\begin{array}{ll}\text { Diterima } & : \text { 12 Februari } 2020 \\ \text { Disetujui } & : 28 \text { Februari } 2020 \\ \text { Diterbitkan } & : 29 \text { Februari 2020 }\end{array}$

\begin{abstract}
Abstrak: Pengembangan peternakan berbasis ternak lokal merupakan salah satu strategi pembangunan daerah yang potensial. Ternak ayam buras merupakan salah satu ternak lokal yang berpotensi untuk dikembangkan, di negara berkembang. Berkembangknya wisata Geopark Ranah minang di Nagari Silokek dibutuhkan sumberdaya manusia yang sehat, cerdas dan berpendidikan. Pengembangan ayam buras sebagai ternak lokal dapat mempunyai peran untuk hal tersebut. Pada pengembagan ayam buras di Nagari Silolek perlu dikaji potensi pengembangannya. Penelitian ini menggunakan metode survey, dengan mengumpulkan informasi dari sebagian sampel untuk mewakili populasi. Pengambilan data menggunakan metode purposive sampling. Data yang dipakai adalah data primer dan sekunder. Data sekunder diperoleh dari BPS Kabupaten Sijunjung, Dinas Pertanian Kabupaten Sijunjung, BPP Kecamatan Sijunjung, Kantor Wali Nagari Silokek. Data primer diperoleh dengan melakukan survey dan wawancara langsung. Hasil penelitian menunjukkan bahwa ternak ayam buras mempunyai potensi untuk dikembangkan di Nagari Silokek sebagai kawasan Geopark Ranah Minang beberapa potensi yang ada meliputi bibit yang ada, bahan pakan lokal, pengalaman yang ada, manajemen pemeliharaan yang tidak sulit, meningkatkan kesejateran dan ketahanan pangan masyarakat, ayam, lebih tahan penyakit, warisan budaya serta adanya kelembagaan atau pasar sebagai faktor pendukung. Potensi pengembangan ayam buras di Nagari Silokek melalui perbaikan genetik, peningkatan jumlah populasi, perbaikan manajemen pemeliharaan dan pemanfaatan secara efektif sarana dan prasarana.
\end{abstract}

Kata Kunci: buras, geopark, potensi, pakan, pangan

\begin{abstract}
The development of local livestock based livestock is one of the potential regional development strategies. Free-range chicken is one of the local animals that have the potential to be developed, in developing countries. The development of the Minopark Geopark tourism in Nagari Silokek requires healthy, intelligent and educated human resources. The development of native chickens as local livestock can have a role for this. In developing free-range chickens in Nagari Silolek, it is necessary to study its development potential. This study uses a survey method, by gathering information from some samples to represent the population. Retrieval of data using purposive sampling method. The data used are primary and secondary data. Secondary data were obtained from BPS Sijunjung Regency, Sijunjung Regency Agriculture Office, Sijunjung District BPP, Wali Nagari Silokek Office. Primary data obtained by conducting surveys and direct interviews. The results showed that domestic poultry has the potential to be developed in Nagari Silokek as a Ranah Minang Geopark region. Some potentials include existing seeds, local feed ingredients, existing experience, maintenance management that is not difficult, improving welfare and food security of the community, chickens, more resistant to disease, cultural heritage and the presence of institutions or markets as supporting factors. Potential development of free-range chickens in Nagari Silokek through genetic improvement, increasing population numbers, improving maintenance management and effective utilization of facilities and infrastructure.
\end{abstract}

Keywords: native chiken, geopark, potential, feed and food. 


\section{Pendahuluan}

Pembangunan kawasan agribisnis berbasis peternakan merupakan salah satu alternatif program yang diharapkan dapat menjawab tantangan dan tuntutan pembangunan yaitu meningkatkan pendapatan dan kesejahteraan masyarakat . Pengembangan peternakan berbasis ternak lokal merupakan salah satu strategi pembangunan daerah yang potensial karena sangat relevan dengan keadaan daerah tersebut. Ternak ayam buras merupakan salah satu ternak lokal yang berpotensi untuk dikembangkan, di negara berkembang, usaha ternak ayam lokal berperan penting dalam meningkatkan pendapatan masyarakat karena usaha tersebut melibatkan sebagian besar penduduk miskin [1].

Nagari Silokek adalah salah satu nagari (desa) yang ada di Kecamatan Sijunjung, Kabupaten Sijunjung. Pada awalnya tidak ada kelihatan yang menonjol di nagari ini, namun setelah penetapan kawasan Geopark Ranah Minang Silokek pada tahun 2018 membuat nagari ini menjadi perbincangan banyak orang dan banyak pembangunan yang dilakukan termasuk pengembangan peternakan [2].

Pengembangan kawasan Geopark Ranah Minang Silokek ini diharapkan mampu menstimulus aktivitas ekonomi bagi masyarakat dan pembangunan yang berkelanjutan dan berkesinambungan. Terwujudnya Pengembangan kawasan Geopark ini dengan sendirinya akan sangat berdampak terhadap peningkatan kesejahteraan masyarakat disekitar kawasan Geopark Ranah Minang Silokek dan Kabupaten Sijunjung secara umumnya [2].

Sebagai kawasan wisata Nagari Silokek membutuhkan ketahanan pangan masyarakat serta sumberdaya manusia yang sehat, cerdas dan berpendidikan. Pengembangan ayam buras sebagai ternak lokal dapat mempunyai peran untuk hal tersebut karena ayam buras merupakan sumber protein hewani yang sehat dan mempunyai gizi yang baik, selain itu pengembangan ayam buras di Nagari Silokek juga dapat meningkatkan kesejahteraan masyarakat sehingga masyarakat mampu melanjutkan sekolah ke jenjang yang lebih tinggi.

Berkembangnya wisata Geopark Ranah Minang di Nagari Silokek maka selain untuk ketahanan pangan masyarakat dan peningkatan kesejahteraan masyarakat, pengembangan ayam buras di Nagari Silokek juga dapat berperan sebagai kuliner khas di kawasan wisata geopark nantinya dengan cara pengolahan daging ayam buras pasca panen. Pembangunan Nagari Silokek dengan dijadikannya Silokek menjadi geopark nasional yang dinamakan "Geopark Ranah Minang Silokek" akan menjadi peluang pasar yang sangat menjanjikan untuk ayam buras, hal ini karena dengan menjadikan nagari silokek menjadi daerah wisata akan berkembang juga warung makan dan kuliner-kuliner untuk wisatawan yang berbasis sumber daya lokal seperti ayam buras.

Rasa daging ayam buras yang khas dan disukai sebagian besar masyarakat merupakan faktor pendukung pada pengolahan ayam buras pasca panen menjadi kuliner khas di kawasan Geopark Ranah Minang Nagari Silokek Kabupaten Sijunjung. Pada pengembangan ayam buras di Nagari Silolek sebagai kawasan Geopark perlu dikaji potensi pengembangan ayam buras di daerah tersebut sebagai dasar dan acuan pegembangan ternak ayam buras kedepannya. Sehingga tidak menganggu pembangunan lainnya.

\section{Metodologi Penelitian}

\subsection{Waktu dan tempat penelitian}

Penelitian ini dilaksanakan di Kabupaten Sijunjung terutama di Nagari Silokek. Nagari Silokek mempunyai 2 Jorong, yaitu Jorong Tanjung Medan dan Sangkiamo. Penelitian ini dilaksanakan dalam jangka waktu 52 (lima puluh dua) hari kalender atau terhitung mulai tanggal 26 Oktober sampai dengan 16 Desember 2019.

\subsection{Metode penelitian}

Penelitian ini menggunakan metode survey, dengan mengumpulkan informasi dari sebagian sampel untuk mewakili populasi. Pengambilan data menggunakan metode purposive sampling. Purposive sampling merupakan metode pengambilan data yang didasarkan atas tujuan dan pertimbangan tertentu dari peneliti.

Adapun data yang dipakai adalah data primer dan sekunder. Data sekunder atau studi literatur: diperoleh dari BPS Kabupaten Sijunjung, Dinas Pertanian Kabupaten Sijunjung, BPP Kecamatan Sijunjung, Kantor Wali Nagari Silokek. Data primer: diperoleh dengan melakukan survey/pengamatan dan wawancara langsung dengan masyarakat petani/peternak di Nagari Silokek oleh Tim Peneliti serta FGD (focus group discussion) dengan pihak terkait.

\subsection{Populasi dan sampel}

Populasi pada penelitian ini adalah semua petani dan peternak yang berada di Nagari Silokek. Sampel adalah bagian dari jumlah dan karakteristik yang dimiliki oleh populasi tersebut. Sampel yang diambil dari populasi harus betul-betul representatif (mewakili).

Penentuan jumlah sampel dilakukan dengan cara penghitungan statistik yaitu dengan menggunakan Rumus Slovin. Rumus Slovin digunakan untuk menentukan ukuran sampel dari populasi yang telah diketahui jumlahnya sebanyak 228 kepala keluarga (KK) petani, yaitu Jorong Tanjung Medan 120 KK dan Jorong Sangkiamo 108 KK. Untuk tingkat presisi yang ditetapkan dalam penentuan sampel adalah $15 \%$. 


\section{Rumus Slovin [3] :}

$\mathrm{n}=\mathrm{N}:\left[1+\mathrm{N}(\mathrm{e})^{2}\right]$

Keterangan:

$$
\mathrm{n}=\text { Ukuran sampel }
$$

$\mathrm{N}=$ Ukuran Populasi

$\mathrm{e}=$ Kelonggaran $/$ ketidaktelitian karena kesalahan pengambilan sampel yang dapat ditolerir, kemudian di kuadratkan. [3].

Berdasarkan Rumus Slovin, maka besarnya penarikan jumlah sampel penelitian adalah:

$$
\begin{aligned}
& \mathrm{n}=228:\left[1+228(0,15)^{2}\right] \\
& \mathrm{n}=37,19 \mathrm{KK}
\end{aligned}
$$

Sehingga dibulatkan menjadi 37 KK. Sampel diambil dengan teknik purposive sampling dengan kriteria rumahtangga yang bermata pencaharian sebagai petani dan peternak masing-masing sebanyak $37 \mathrm{KK}$

\section{Hasil dan Pembahasan}

\subsection{Kondisi peternakan ayam buras di Nagari Silokek}

\subsubsection{Jumlah dan jenis usaha ternak ayam buras di} Nagari Silokek

Pemeliharaan ternak unggas, pada umumnya juga dilakukan dengan skala yang relatif kecil, yaitu $57,7 \%$ memiliki < 10 ekor dan 38,5\% memiliki $10-25$ ekor. Hanya 3,8\% dari masyarakat yang memiliki ayam >25 ekor. Selengkapnya tergambar pada tabel berikut :

\begin{tabular}{|c|c|c|c|}
\hline Karakteristik & Uraian & $\begin{array}{c}\text { Jumlah } \\
\text { Responden } \\
\text { (orang) }\end{array}$ & $(\%)$ \\
\hline \multirow{3}{*}{$\begin{array}{l}\text { Jumlah Ternak } \\
\text { Dipelihara }\end{array}$} & $<10$ ekor & 14 & 57,7 \\
\hline & $10-25$ ekor & 11 & 38,5 \\
\hline & $>25$ ekor & 1 & 3,8 \\
\hline \multicolumn{2}{|c|}{ Total } & 26 & 100 \\
\hline
\end{tabular}

Tabel 1. Jumlah Ayam Buras yang Dipelihara Peternak di Nagari Silokek.

Jumlah kepemilikan ternak seperti yang tergambar pada tabel di atas, menjelaskan bahwa ternak masih menjadi komoditi sampingan dan belum dipelihara secara serius oleh masyarakat Nagari Silokek. Kemudian jumlah kepemilikan ternak yang kecil juga belum bisa menjadi penopang utama perekonomian masyarakat.

\subsubsection{Karakteristik Peternak Ayam Buras di Nagari Silokek}

Karakteristik peternak ayam buras di Nagari Silokek yang meliputi umur, jenis kelamin,
Pendidikan dan pengalaman beternak dapat dilihat pada Tabel 2 di bawah ini.

Tabel 2. Karakteristik Peternak Ayam Buras di Nagari Silokek

\begin{tabular}{lc}
\hline Karakteristik & Persentase (\%) \\
\hline 1. Umur : & \\
- <25 th & 3,8 \\
$-25-55$ th & 69,2 \\
- 55 th & 26,9 \\
\hline 2. Jenis Kelamin : & \\
- Laki-laki & 34,6 \\
- Perempuan & 65,4 \\
\hline 3. Pendidikan : & \\
- Tidak sekolah & 30,8 \\
- SD / sederajat & 50 \\
- SLT/ sederajat & 7,7 \\
- SLTA / sederajat & 11.5 \\
- Sarjana / sederajat & 0 \\
\hline 4.Pengalaman beternak : & \\
- < 5 th & 30,8 \\
- 5-10 th & 26,9 \\
- > 10 th & 42,3 \\
\hline
\end{tabular}

Dari hasil penelitian pada Tabel 2 tersebut dapat disimpulkan bahwa pada umumnya peternak di Nagari Silokek masih berusia produktif (25-55 tahun), yaitu dengan rincian besaran $66,7 \%$ untuk peternak sapi dan kerbau, $100 \%$ untuk peternak kambing dan $69,2 \%$ peternak unggas. Kondisi ini merupakan kondisi yang sangat mendukung dalam pembangunan peternakan di Nagari Silokek. Peternak yang berumur produktif akan lebih efektif mengelola usahanya dibandingkan peternak yang sudah tua maupun yang masih terlalu muda [4].

Pada Tabel 2 juga terlihat bahwa jenis kelamin peternak ayam buras di Nagari Silokek adalah perempuan, hal ini karena usaha peternakan ayam buras yang dijalankan masih bersifat sampingan sehingga tidak memerlukan tenaga kerja lebih dan bisa dijalankan oleh perempuan. Pada tingkat pendidikan terlihat bahwa pada umumnya peternak ayam buras di Nagari Silokek adalah SD/sederajat. Tingkat Pendidikan akan berpengaruh pada pola pikir dan kreatifitas dalam kehidupan sehari-hari. Pendidikan berkaitan erat dengan rasionalisasi pemikiran seseorang dalam mengambil keputusan yang lebih bijak, selain itu tingkat pengetahuan yang lebih tinggi akan merangsang pembaharuan di bidang teknis, ekonomi dan aspek lain [5]. Dengan demikian, tingkat pendidikan peternak di Nagari Silokek dapat dikatakan belum baik karena sebagian besar berpendidikan rendah.

Dari tabel di atas dapat ditarik informasi bahwa sebagian besar peternak di Nagari Silokek sudah memiliki banyak pengalaman dalam beternak ayam buras lebih dari 10 tahun, hal ini disebabkan usaha ternak ayam buras merupakan usaha turun temurun masyarakat dan dengan pemeliharaan yang relatif 
lebih mudah yaitu dengan melepaskan ayam untuk mencari pakan sendiri dengan pola pemeliharaan secara ektensif dan semi intensif. Umur dan pengalaman mempengaruhi kemampuan berusaha. Peternak yang berpengalaman akan memiliki kapasitas pengelolaan usaha yang lebih matang dan dengan pengalaman yang cukup, peternak dapat pula mengetahui kekurangan atau permasalahan yang timbul serta dapat memprediksi apa yang akan terjadi bila tindakannya dalam menangani masalah tersebut [6].

\subsection{Potensi Pengembangan Ayam Buras di Nagari Silokek}

Ayam kampung yang ditemukan di Nagari silokek adalah ayam kampung lokal dan ayam kampung persilangan (ayam bangkok). Ayam kampung ini berpotensi untuk dikembangkan di Nagari Silokek. Beberapa faktor pendukung pengembangan potensi ayam Buras di Nagari Silokek adalah :

\subsubsection{Bibit}

Ayam buras merupakan sumber daya genetik lokal yang sangat berharga sehingga perlu dilestarikan dan dikembangkan [7]. Populasi ayam buras cukup banyak di Nagari Silokek yaitu sekitar 600 ekor [2] yang dipelihara oleh 120 orang atau setara dengan 30\% kepala keluarga di Nagari Silokek, sehingga bibit untuk ayam buras sebenarnya sudah tersedia di Nagari Silokek dan ini merupakan salah satu potensi untuk pengembangan ayam buras di Nagari Silokek tetapi perlu perbaikan mutu genetik.

\subsubsection{Kandang dan peralatan}

Kandang adalah hal penting dalam usaha ternak, baik ayam buras maupun ternak lainnya, karena kandang berfungsi untuk tempat beristirahat, tempat berlindung, tempat bereproduksi dan tempat untuk berproduktivitas [8]. Kandang yang dibutuhkan untuk usaha ternak ayam kampung cukup sederhana, hemat lahan dan biaya kandang yang tidak mahal. Hal inilah yang menjadi salah satu faktor pendukung potensi pengembangan ayam kampung di Nagari Silokek.

Kandang ayam buras dapat terbuat dari bambu, kayu atau terpal. Usaha peternakan yang sudah dijalankan oleh masyarakat Nagari silokek walaupun tergolong dalam usaha sampingan tetapi sudah memiliki kandang yang sederhana sehingga untuk pengembangan ayam kampung di Nagari Silokek hanya perlu perluasan kandang, di bawah ini adalah beberapa contoh kandang ayam peternak Nagari Silokek dimana desain kandang dibuat bertingkat sehingga dapat menghemat lahan. Hal ini cocok dengan keadaan topografi Nagari Silokek dengan keterbatasan lahan datar.

Peralatan kandang ayam buras juga sederhana hanya dibutuhkan tempat pakan, tempat minum dan lampu. Tempat pakan dan tempat minum ini juga bisa dibuat dari bambu sehingga tidak memerlukan biaya yang banyak, bambu juga banyak tersedia di Nagari Silokek. Peralatan kandang berupa lampu hanya dibutuhkan ketika fase awal (starter), setelah itu ayam kampung tidak memerlukan lampu lagi.

\subsubsection{Permodalan}

Permodalan yang diperlukan dibutuhkan untuk pengembangan ayam buras tidaklah terlalu besar seperti ternak dibandingkan ternak lainnya. Usaha ternak ayam buras yang dilakukan di Nagari Silokek walaupun termasuk usaha sampingan tetapi permodalannya berasal dari modal sendiri [12], hal ini menjadi potensi pengembangan ayam buras di Nagari Silokek karena kondisi di lapangan sudah 30\% masyarakat Nagari Silokek yang mempunyai ternak ayam skala kecil dan ini sudah merupakan modal bagi masyarakat di Nagari Silokek.

Beberapa penelitian yang telah dilakukan menyatakan bahwa permodalan ayam buras pada umumnya merupakan permodalan sendiri, modal sepenuhnya pada peternak ayam kampung berasal dari modal sendiri yang modalnya tidak terlalu besar. Pemerintah berperan penting dalam penyediaan modal usaha ternak ayam lokal untuk meningkatkan skala usaha, diperlukan stratifikasi wilayah pengembangan ayam lokal di pedesaan [9].

\subsubsection{Ayam kampung sebagai penunjang ketahanan pangan keluarga}

Daging ayam buras merupakan salah satu sumber protein hewani yang berperan penting dalam ketahanan pangan masyarakat Nagari Silokek, ayam buras mempunyai nilai gizi yang baik untuk dikonsumsi sehingga bagus untuk mencegah stunting dan meningkatkan kecerdasan anak. Ayam kampung disukai orang karena dagingnya yang kenyal, tahan pengolahan (tidak hancur ketika dimasak) dan "berisi", tidak lembek dan tidak berlemak sebagaimana ayam ras, kandungan nutrisinya yang lebih tinggi. Dagingnya mengandung 19 jenis protein dan asam amino yang tinggi, kadar lemaknya juga relatif lebih rendah daripada ayam broiler. Kotoranya juga bisa dimanfaatkan sebagai pupuk tanaman maupun pakan ikan. Sebagai sumber protein hewani, telur dan daging ayam buras mengandung asam amino esensial yang sangat dibutuhkan oleh tub uh dan berperan dalam meningkatkan kesehatan masyarakat [10].

\subsubsection{Peningkatan kesejahteraan masyarakat}

Usaha ternak ayam buras dapat meningkatkan kesejahteraan masyarakat, demikian juga halnya di Nagari Silokek dimana pengembangan ternak ayam buras ini berpotensi meningkatkan kesejahteraan masyarakat karena selain berfungsi untuk ketahanan pangan keluarga juga dapat meningkatkan pendapatan masyarakat, dengan peningkatan 
populasi ayam buras maka kebutuhan sebagai sumber pangan akan tercukupi dan bahkan masyarakat dapat menjual ayam buras dimana hasil penjualan ayam ini dapat menambah pendapatan keluarga sehingga kesejahteraan meningkat.

Pengembangan ayam lokal di Indonesia hendaknya diarahkan pada peningkatan skala kepemilikan dan perbaikan teknik budi daya dengan mengubah pola pemeliharaan dari pola ekstensif tradisional (sistem umbaran) ke usaha intensif komersial sehingga dapat meningkatkan pendapatan petani dan kesempatan kerja. Upaya pengembangan tersebut diharapkan pula dapat menggairahkan perekonomian dan sekaligus meningkatkan pendapatan masyarakat, terutama di pedesaan [8].

\subsubsection{Ayam buras lebih tahan penyakit}

Ayam buras lebih tahan penyakit dibandingkan ayam broiler, sehingga manajemen pemeliharaannya tidaklah terlalu sulit. Ayam lokal memiliki ketahanan yang lebih baik terhadap penyakit, terutama AI, dibanding ayam ras pada umumnya karena memiliki frekuensi gen antivirus $\mathrm{Mx}+$ yang lebih banyak. Pemberian obat alami dapat mencegah penyakit akibat infeksi virus, parasit, protozoa, dan bakteri [8].

Pemberian obat-obat dan ramuan herbal dengan memanfaatkan bahan-bahan herbal yang tersedia di Nagari Silokek seperti jahe, kunyit temu lawak dan daun sirih dapat meningkatkan daya tahan dan produktivitas pada ayam buras.

\subsubsection{Potensi Bahan Pakan Lokal}

Nagari Silokek mempunyai areal persawahan sebanyak 28,10 ha sehingga hal ini berpotensi menghasilkan dedak padi sebanyak 14 ton per ha per panen. Dedak padi ini dapat dimanfaatkan sebagai salah satu bahan pakan pada unggas, untuk meningkatkan kualitas nutrisi pakan unggas keong penambahan keong mas dapat dilakukan, dimana keong mas ini juga ditemui di Nagari Silokek yang merupakan hama pada padi sawah, Selain ini limbah rumah tangga juga dapat diberikan sebagai bahan pakan ayam buras, hal ini sudah dilakukan oleh beberapa masyarakat nagari silokek hanya perlu pendampingan untuk memformulasikan ransum ayam buras yang sesuai atau mendekati kebutuhan nutrisi unggas sehingga produktivitas meningkat.

Dedak padi mempunyai kandungan nutrisi yang cukup akan tetapi tinggi serat kasar. Dedak padi mengandung energi metabolisme $1650 \mathrm{kkal} / \mathrm{kg}$ dan protein kasar $13 \%$, akan tetapi dedak padi tinggi serat kasar yaitu $13 \%$ [11]. tepung keong mas dapat digunakan sebagai bahan pakan sumber protein karena mempunyai kandungan protein kasar yang hamper sama dengan tepung ikan. tepung keong mas mengandung protein kasar 56,06\% [12].

\subsubsection{Pemeliharaan ayam kampung di Nagari Silokek} Warisan Budaya Leluhur

Masyarakat Nagari Silokek sudah banyak yang memelihara ayam kampung yang merupakan warisan budaya turun temurun dari nenek moyang mereka. Berdasarkan survey yang dilakukan di Nagari Silokek bahwa 30\% kepala keluarga masyarakat di Nagari Silokek melakukan pemeliharaan ayam buras sistem pemeliharaannya lebih mengarah ke ekstensif karena hampir tidak adanya manajemen pemeliharaan [2]. Keadaan ini merupakan suatu potensi pengembangan ayam buras di Nagari Silokek akan tetapi peternak perlu bimbingan dan inovasi teknologi untuk meningkatkan produktivitas ternak ayam buras di Nagari Silokek.

Sistem pemeliharaan ayam buras yang ekstensif ini bukan hanya terjadi di Nagari Silokek akan tetapi sebagian besar wilayah pedesaan di seluruh Indonesia. Ayam lokal yang dipelihara oleh peternak di pedesaan umumnya dengan system pemeliharaan yang ekstensif tradisional, ayam dibiarkan berkeliaran mencari pakan sendiri untuk memenuhi kebutuhan hidupnya dan peranan peternak sangat minim, hanya sesekali saja menyediakan ransum dan mengandangkan ayamnya [13], sehingga untuk peningkatan produktivitas ayam lokal diperlukan langkah dan strategi, diantaranya pengarahan system pemeliharaan ayam lokal menuju intensif.

\subsubsection{Kelembagaan dan pasar}

Hasil survey di lapangan menunjukkan bahwa kelembagaan untuk mendukung pengembangan ayam buras di Nagari Silokek cukup mendukung diantaranya sudah adanya kelompok dan penyuluh, Unit Pelayanan Kesehatan Hewan (UPT Keswan) yang berada cukup dekat dari Nagari Silokek, serta adanya dukungan dan bantuan dari instansi terkait seperti dinas peternakan kabupaten untuk mendukung potensi peternakan ayam buras seperti adanya program bantuan bibit ayam buras yang pernah dilakukan oleh Dinas Peternakan Kabupaten Sijunjung secara gratis ke kelompok ternak di nagarinagari Kabupaten Sijunjung.

Ayam buras mempunyai rasa yang khas sehingga lebih digemari oleh masyarakat sehingga untuk pemasaran ayam kampung tidak menjadi kendala. Berdasarkan hasil survey di lapangan pemasaran ayam buras di Nagari Silokek hanya untuk memenuhi sebagian permintaan masyarakat yang berada di Nagari Silokek sehingga belum bisa dipasarkan ke luar Nagari Silokek. Berkembangnya pembangunan Nagari Silokek dengan dijadikannya Silokek menjadi geopark nasional yang dinamakan "Geopark Ranah Minang Silokek” akan menjadi peluang pasar yang sangat menjanjikan untuk ayam buras, hal ini karena dengan menjadikan nagari silokek menjadi daerah wisata akan berkembang juga warung makan dan 
kuliner-kuliner untuk wisatawan yang berbasis sumber daya lokal seperti ayam buras.

\section{Kesimpulan}

Peternakan ayam buras mempunyai potensi untuk dikembangkan di Nagari Silokek sebagai Kawasan Geopark Nasional sebagai penunjang ketahanan pangan dan meningkatkan kesejahteraan masyarakat melalui perbaikan genetik, peningkatan jumlah populasi, perbaikan manajemen pemeliharaan dan pemanfaatan secara efektif sarana dan prasarana yang mendukung. Sebanyak 30\% masyarakat di Nagari Silokek sudah mempunyai usaha ayam buras dengan sistem pemeliharaan ekstensif dan semi intensif.

\section{Referensi}

[1] Sonaiya, E.B. 2007. Family poultry, food security and the impact of HPAI. J. World's Poult. Sci. 63: 132-138.

[2] BAPPEDA Kabupaten Sijunjung. 2018. Kajian Geologi dan Biodiversity Kabupaten Sijunjung. BAPPEDA Kabupaten Sijunjung, Sijunjung.

[3] Sugiyono. Metode Penelitian Pendidikan Pendekatan Kuantitatif, kualitatif, dan R\&D. Bandung: Alfabeta.

[4] Adiwilaga, A. 2010 Ilmu Usahatani. Penerbit Alumni. Bandung.

[5] Suntoro, 2001. Pengaruh Residu Penggunaan Bahan Organik, Dolomit dan $\mathrm{KCl}$ pada Tanaman Kacang Tanah (Arachis hypogeae. L.) pada Oxic Dystrudept di Jumapolo, Karanganyar, Habitat, 12(3) 170-177.

[6] Soeharjo, A dan Patong. 1973. Sendi - Sendi Pokok Usahatani. Jurusan Ilmu Sosial Ekonomi Pertanian. Institut Pertanian Bogor, Bogor.

[7] Efdi, D. 2017. Rencana Kerja Tahunan Penyuluh (RKTP). Unit Pelaksana Teknis Badan-Balai Penyuluhan Kecamatan (UPTB-BPK). Sijunjung.

[8] Suprijatna, E. U, Atmomarsono. R, Kartasudjana. 2005. Ilmu Dasar Ternak Unggas. Penebar Swadaya. Jakarta.

[9] Nataatmijaya, G.A. 2010. Pengembangan Potensi Ayam Lokal Untuk Menunjang Peningkatan Kesejahteraan Petani. Jurnal Litbang Pertanian. 29 (4) : 131-138.

[10] ILO-PCdP2 UNDP. 2011. Kajian Ayam Buras dengan Pendekatan Rantai Nilai dan Iklim Usaha di Kabupaten Boven Digoel. Laporan Studi . UNDP Digoel.

[11] Triani, H. D. 2012. Kajian Pengolahan Biji Alpukat dan Kulit Pisang Sebagai Sumber Energi dalam Ransum Puyuh serta Pengaruhnya Terhadap Performan dan Kualitas Telur. Tesis. Pasca Sarjana Universitas Andalas. Padang.

[12] Dewi, S.F. 2014. Pemanfaatan Tepung Keong Mas (Pomacea canaliculata) Sebagai Substitusi
Tepung Ikan Pada Pakan Udang Vannamei (Litopenaeus vannamei) Terhadap Nilai Kecernaan Serat Kasar dan Bahan Eekstrak Tanpa Nitrogen (BETN). Skripsi. Fakultas Perikanan dan Kelautan Universitas Airlangga. Surabaya.

[13] Suprijatna, E. 2010. Strategi Pengembangan Ayam Lokal Berbasi Sumberdaya Lokal dan Berwawasan Lingkungan. Seminar Nasional Unggas Lokal ke- IV. Universitas Diponegoro. Semarang. 